\section{The Pontifical Academy of Science}

$\mathrm{F}^{\mathrm{N}}$ EDERICO CESI of the Princes of Acquasparta, John Heck, a Dutchman, Francesco Stelluti of Fabriano and Anastasio de Filiis, Count-Palatino of Terni, founded at Rome on August 17, 1603, an Academy of Science and called it the Lynceorum philosophorum Ordo seu Consessus seu Academia with the motto: Sagacius ista. Galileo Galilei joined it after 1610 .

Finis eius, they proclaimed, est rerum cognitionem et sapientiam non solum acquirere, recte pieque simul vivendo, sed et hominibus voce et scriptis ubique ullius noxa pacifice pandere.

Though its fortunes varied, the Academy's aims and activities were always scientific.

In 1847, Pope Pius IX, continuing the interest that previous popes had shown, decided to restore the Academy with a new constitution; he reconfirmed its possession of the Senatorial Palace on the Campidoglio, began the regular publication of the "Acts", and placed it in direct dependence upon the pope and his government with the new title of the "Pontifical Academy of the New Lincei". Later, in 1877, it was still further enlarged by Leo XIII, who increased the number of its fellows (Soci) and began the publication of the "Memorials".

Finally, in 1922, His Holiness Pius XI changed its residence, which after 1870 had been the Palace of the Apostolic Chancellery, to the Vatican Gardens, giving it the beautiful little house of Pius IV which is one of Ligorio's finest works of art, and providing generously for its financial rehabilitation. In 1923, he altered its name to "Pontifical Academy of Science-the New Lincei".

Following the Papal Letter, "In multis solaciis" of October 28, 1936, and in view of the great import. ance attaching to the Academy itself, he decided to adapt it to the new and more obvious needs of the times by providing it with a new constitution and a complete revision of its membership, keeping, how ever, for its former members their rank of 'fellows'.

This new Academy, "The Pontifical Academy of Science", is directly dependent upon the Pope himself, and is composed of seventy 'Pontifical academi. cians', appointed by the Pope, belonging to every nation and religion, chosen from among the most famous men of science in the world. To these are added the 'Supernumerary academicians' by reason of their office, and the 'Honorary academicians' by reason of their good services towards the Academy itself. Ab eis itaque Apostolica haec Sedes id auxilii ac decoris expectat ac praestolatur, cuius hic veluti doctorum hominum Senatus, seu "Scientificus" Senatus, certum portendit auspicium.

The members of the Academy are as follow :

Presidente, Prof. P. Agostino Gemelli, O.F.M. ; Segretario, Comm. Prof. Giuseppe Armellini; Tesoriere, M. se Gr. Uff. Prof. Lepri Giuseppe; Bibliotecario, P. Don Anselmo Albareda, O.S.B.; Censori, S. E. Gr. Uff. Prof. Emilio Bianchi, S. E. Gr. Uff. Prof. Filippo Bottazzi, Cancelliere dell' Accademia, Comm. Dott. Pietro Salviucci.

Accademici Pontifici Onorari. Emo Card. Gaetano Bisleti, Emo Card. Eugenio Pacelli, Emo Card. Francesco Marchetti Selvaggiani, P. pe Ludovico Chigi Albani della Rovere, Prof. Pietro De Sanctis.
Accademici Pontifici. Abderhalden, Emil (Halle), Amaldi, Ugo (Roma), Armellini, Giuseppe (Roma), Barrois, Charles (Lille), Bianchi, Emilio (Milano), Birkhoff, George David (Cambridge, Mass.), Bjerknes, Vilhelm Frimann Koren (Oslo), Bohr, Niels (Kopenagen), Boldrini, Marcello (Milano), Bottazzi, Filippo (Napoli), Branly, Edouard (Paris), Buytendijk, F. J. J. (Groningen), Carathéodory, Constantin (München), Carrel, Alexis (New York), Castellani, Aldo (Roma), Colonnetti, Gustavo (Torino), Crocco, Gaetano Arturo (Roma), Cuenot, Lucien (Nancy), Dal Piaz, Giorgio (Padova), Debye, Peter (BerlinDahlem), De Filippi, Filippo (Roma), de la Vallée Poussin, Charles (Louvain), Fauvel, Pierre (Angers), Gemelli, Agostino (Milano), Gherzi, Ernesto (Zi-kawei, Shanghai), Ghigi, Alessandro (Bologna), Gilson, Gustave (Louvain), Giordani, Francesco (Napoli), Giorgi, Giovanni (Roma), Godlewski, Emil (Krakow), Gola, Giuseppe (Padova), Grégoire, Victor (Louvain), Guidi, Camillo (Torino), Guthnick, Paul (BerlinNeubabelsborg), Houssay, Bernardo (Buenos Aires), Keesom, Wilhelmus Hendrikus (Leiden), Lemaître, Georges (Louvain), Lepri, Giuseppe (Roma), LeviCivita, Tullio (Roma), Lombardi, Luigi (Roma), Luigioni, Paolo (Roma), Marconi, Guglielmo (Roma), Mendes Correa, Antonio Augusto (Porto), Michotte, van den Berch Albert (Louvain), Millikan, Robert Andrews (Pasadena, Calif.), Morgan, Thomas Hunt (Pasadena, Calif.), Nobile, Umberto (Napoli), Noyons, Adriaan Karel Marie (Utrecht), Panetti, Modesto (Torino), Parravano, Nicola (Roma), Pensa, Antonio (Pavia), Petritsch, Ernst Felix (Wien), Picard, Emile (Paris), Pistolesi, Enrico (Pisa), Planck, Max (Berlin), Rasetti, Franco (Roma), Rondoni, Pietro (Milano), Lord Rutherford of Nelson (Cambridge), Schrödinger, Erwin (Graz), Sherrington, Sir Charles (Oxford), Silvestri, Filippo (Portici), Sperti, George (Cincinnati, Ohio), Taylor, Hugh Stott (Princeton, N.J.), Toniolo, Renato (Bologna), Tschermak-Seysenegg, Armin (Prag), Vallauri, Giancarlo (Torino), Vercelli, Francesco (Trieste), Volterra, Vito (Roma), Whittaker, Edmund Taylor (Edinburgh), Zeeman, Pieter (Amsterdam).

Accademici Pontifici Soprannumerari. Albareda, Anselmo, prefetto della Biblioteca Apostolica Vaticana; Gatterer, Aloys, prefetto del Laboratorio Astrofisico della Specola Vaticana; Mercati, Angelo, prefetto dell' Archivio Segreto Vaticano; Schmidt, Wilhelm, direttore scientifico del Museo Missionario etnologico lateranense; Stein, Johann, direttore della Specola Vaticana.

\section{University Events}

Cambridge.-Prof. W. J. de Haas, of Leyden, has been appointed Scott lecturer for the year 1937-38.

Prof. L. T. Hogben will lecture in the Zoological Lecture Room on Wednesday, February 10, at 5 p.m., on "Some Neglected Aspects of the Species Problem".

OXFORD. - The following appointments to professorships have been made: Mr. C. N. Hinshelwood, Trinity College, to the Dr. Lee's chair of chemistry; Mr. Hugh Cairns, Balliol College, to the Nuffield chair of surgery; Mr. R. R. Macintosh, to the Nuffield chair of anæsthetics. 